\title{
An Empirical Study on the Influencing Factors and Countermeasures of Inflation in China
}

\author{
Shiyun Liang \\ School of Economics, Jinan University, Guangzhou, China \\ Email: liangsy2006@163.com
}

How to cite this paper: Liang, S.Y. (2017) An Empirical Study on the Influencing Factors and Countermeasures of Inflation in China. American Journal of Industrial and Business Management, 7, 513-521. https://doi.org/10.4236/ajibm.2017.74037

Received: March 8, 2017

Accepted: April 27, 2017

Published: April 30, 2017

Copyright (c) 2017 by author and Scientific Research Publishing Inc. This work is licensed under the Creative Commons Attribution International License (CC BY 4.0).

http://creativecommons.org/licenses/by/4.0/ (c) (†) Open Access

\begin{abstract}
Since the outbreak of the financial crisis in 2008, China's money supply has been increasing in the context of serious international monetary crisis, which had caused the problem of domestic inflation and become a threat to China's economic development. China's economic structure and development determines that domestic inflation is highly vulnerable to external shocks. At present, the relationship between China and the world is deepening, and economic reform is imperative. This means that the influence of international currency, capital and commodities will have a certain effect on China's economy and inflation through certain transmission mechanism. This paper mainly analyzes the influencing factors of inflation from comprehensive domestic and external shocks in China by quantitative research, and to reveal its main causes in order to put forward the corresponding policy suggestions and promote the healthy development of the national economy.
\end{abstract}

\section{Keywords}

Inflation, Money Supply, External Shock, VAR Model

\section{Introduction}

Since the outbreak of the financial crisis in 2008, the global economy has been under a huge impact. The engine of the world economy US has faced a large number of corporate bankruptcy crisis, with investment and consumption falling sharply. The domestic economy also suffered from the crisis. Consumption, exports declined and there are other shocks caused long-terms effects on China's economy. In order to get rid of the impact of the crisis as soon as possible, promoting economic development, coping with rising unemployment and the deflation and other issues, China has taken a number of measures and policies, including the a 4 trillion investment plan put forward in 2008. Since then, in order 
to alleviate the downward pressure on China's economy, China has maintained a moderately easy monetary policy. In a short period of time, China's economy has shown a recovery situation and its economy has gone through the most difficult year. But at the same time, due to excessive monetary growth and the international shocks, inflation problem has risen. China was facing a rapid growth in money supply, which influences residents living, business investment and other aspects of the economy.

It can be seen from Figure 1 that since 2008 China's generalized M2 currency circulation has been in rapid increase and the total growth of more than $300 \%$. We can see that China's M2/GDP was larger than 2, which means that the M2 currency is much larger than the real need of economic development.

China's inflationary pressures are not just the result of the rapid growth of money supply, but also the result of domestic and foreign economic factors. In an open economic environment, import and export trade, foreign investment return is lower than the domestic and the inflow of foreign capital are likely to further exacerbate the impact of inflation.

Based on situation, this paper aims to explore the causes of inflation in China by empirical research combining the endogenous and external shock factors, and finally provides some policy suggestions on inflation.

This study is divided into four additional sections. Section 2 is dedicated to a review of the literature concerning the effects of increasing rise of M2 stock and the relative theory on the money issue. Section 3 provides a description of the sample and of the methodology adopted. Section 4 shows the results of empirical research and the last section contains the discussion of the results and conclusions and provides the responding countermeasures.

\section{Literature Review}

The study of inflation first appeared in Keynes's "Employment, Interest and Money", Keynes (1936).

It is argued that the volatility in investment demand in aggregate demand is

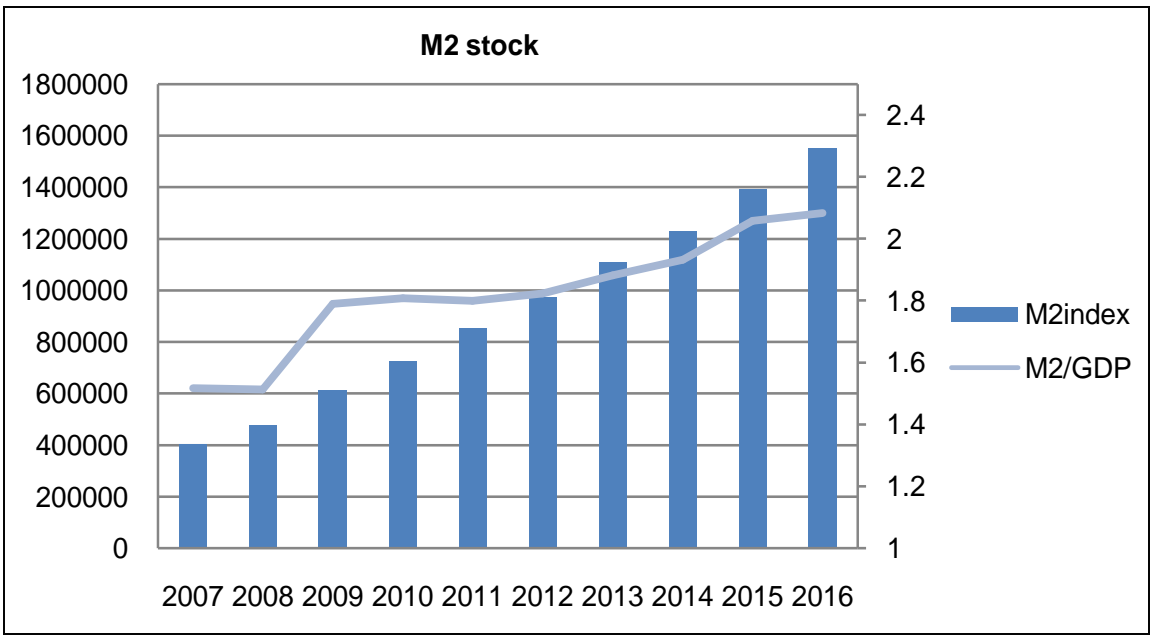

Figure 1. 2008-2014 RMB M2 stock. 
much greater than the demand for consumption, so that the expansion of investment demand will take the role of multiplier and eventually lead to rising prices and inflation. The father of monetarism Friedman (1963) in the American currency history put forward the famous conclusion: the essence of any inflation is the overweight of currency issue, while the money supply is the primary engine of economic production.

Concerning the relationship between money growth and inflation, L Benati in the study investigate the correlation between inflation and the rates of growth of narrow and broad money in the United Kingdom since the 19th century [1]. Empirical evidence points towards a remarkable stability across monetary regimes in the correlation for longer-run trends in the data, but some instability in the short to medium term. Additional evidence from the United States confirms the overall stability of the correlation for the longer-run trends.

DE Rapachuse a structural vector auto regression framework to analyze the effects of a permanent change in inflation on the long-run real interest rate and real output level in 14 industrialized countries [2]. Long-run monetary super neutrality is rejected for all 14 countries using annual data: the results indicate that a permanent increase in inflation lowers the long-run real interest rate in each country; a permanent increase in inflation also increases the long-run real output level in a number of countries.

Zhengquan, He suggests that the US quantitative easing policy will raise the price of commodities to China, and will affect China's monetary policy effect [3]. Zhang Liqing pointed that the US quantitative easing policy will eject a lot of liquidity into the emerging market economies, and may have a negative impact on it [4].

In summary, the influencing factors of inflation are multifaceted in domestic money supply factors and the impact of external shocks. Therefore, based on the existing theoretical on the causes of inflation, this paper makes an empirical test on various concerning factors causing inflation, and provides some policy countermeasures.

\section{Variable Selection and Data Description}

(A) Variable selection

In the empirical research process, this paper chooses the following variables to establish the empirical analysis model:

1) Monetary policy variables RM2. In the domestic environment, China's money supply is mainly determined by the central bank. At present, China's central bank's monetary policy is largely influenced by policy. In this paper, M2 is used as a variable to reflect the monetary stock determined by the currency policy of China.

2) China's inflation variables CPI. The index of the price commonly used is CPI and PPI, CPI is better reflected the price and the cost of home living standards and is more commonly used in the aspects of resident view. Thus the paper select the CPI as a variable index of inflation. 
3) The impact of external impact variables. External shocks are also important factors driving China's inflation, such as the United States easing policy. During the financial crisis, the United States implemented four QE, the dollar's over supply caused federal interest rate at near zero level. Because of a low level of return, international hot money has also poured into China's higher return on investment projects. At the same time, the rising price of international commodities has also pushed up the pressure of cost-driven inflation.

In summary, the variables include: China's broad money supply (RM2), China's consumer price index (CPI), USD/RMB exchange rate (EXR), foreign direct investment (FDI), international commodity price index (CRB), China Foreign Exchange Reserve (RES).

(B) Data description

The data of this paper are analyzed by monthly data respectively. The data was collected from the website of the People's Bank of China, the official website of the Federal Reserve and the WIND database.

\section{Empirical Test}

\subsection{Smoothness Test}

In the process of establishing a VAR model for time series, it is necessary to determine whether the time series is stationary, otherwise it will lead to regression problems. First, we conduct the unit root test to determine the smoothness of the variables. Taking a significant level of 5\%, the results shown in Table 1 .

Table 1. Result of ADF unit root test.

\begin{tabular}{|c|c|c|c|c|}
\hline Varibles & $(\mathrm{C}, \mathrm{T}, \mathrm{L})$ & T-stastics & p-value & Smoothness \\
\hline CPI & $(\mathrm{C}, \mathrm{T}, 12)$ & -0.6131 & 0.9754 & Stationary \\
\hline $\mathrm{dCPI}$ & $(\mathrm{C}, \mathrm{T}, 12)$ & -7.263192 & 0.0000 & Stationary \\
\hline RM2 & $(\mathrm{C}, \mathrm{T}, 12)$ & -1.604307 & 0.7821 & Non-stationary \\
\hline dRM2 & $(\mathrm{C}, \mathrm{T}, 12)$ & -6.167182 & 0.0000 & Stationary \\
\hline EXR & $(\mathrm{C}, 0,12)$ & -5.017896 & 0.0001 & Stationary \\
\hline dEXR & $(\mathrm{C}, 0,12)$ & -8.540224 & 0.0000 & Stationary \\
\hline FDI & $(\mathrm{C}, \mathrm{T}, 12)$ & -1.057897 & 0.9285 & Non-stationary \\
\hline dFDI & $(\mathrm{C}, \mathrm{T}, 12)$ & -3.920798 & 0.0161 & Stationary \\
\hline RES & $(\mathrm{C}, \mathrm{T}, 12)$ & -0.649772 & 0.9731 & Non-stationary \\
\hline dRES & $(\mathrm{C}, \mathrm{T}, 12)$ & -7.633750 & 0.0000 & Stationary \\
\hline AM2 & $(\mathrm{C}, \mathrm{T}, 12)$ & -2.034470 & 0.5736 & Non-stationary \\
\hline dUSM2 & $(\mathrm{C}, \mathrm{T}, 12)$ & -4.109890 & 0.0091 & Stationary \\
\hline TRADEF & $(\mathrm{C}, 0,12)$ & -4.823142 & 0.0001 & Stationary \\
\hline dTRADEF & $(\mathrm{C}, 0,12)$ & -12.69718 & 0.0001 & Stationary \\
\hline CRB & $(\mathrm{C}, \mathrm{T}, 12)$ & -4.534960 & 0.0024 & Stationary \\
\hline $\mathrm{dCRB}$ & $(\mathrm{C}, \mathrm{T}, 12)$ & -10.61541 & 0.0000 & Stationary \\
\hline
\end{tabular}


It can be seen from the ADF test that most variables exist unit roots in the $5 \%$ significance level, indicating that the variables are mostly nonstationary except for CRB and EXR, and then the ADF unit root test is performed again after the first order difference for all variables. Test results listed in the Table 1 above, we can see that the variables after the first-order difference are significantly stable, there is no unit root.

\subsection{Cointegration Test}

The time series must have a integration relationship in the long run to establish the VAR model. That is, there must be a long-term equilibrium between the variables relationship so that the establishment of the VAR model has a stable connection. Therefore, the need for covariance test variables exists.

First we determine the optimal lag of the VAR model. The result was as shown in Table 3.

Table 2 indicates the optimum lag period under different criteria. It can be seen from the data in the table that most criteria show that the optimal lag period of the VAR model is 7 . Thus, the order of the determined cointegration test is 7 .

Followed by cointegration test, the results shown in Table 3.

Table 2. Optimal hysteresis order.

\begin{tabular}{cccccc}
\hline Lag & Log L & LR & FPE & AIC & SC \\
\hline 0 & -2967.84 & NA & $1.41 \mathrm{E}+24$ & 78.31145 & $78.55679^{*}$ \\
1 & -2882.33 & 150.7536 & $8.10 \mathrm{E}+23$ & 77.74561 & 79.95367 \\
2 & -2810.32 & 111.8176 & $6.91 \mathrm{E}+23$ & 77.5346 & 81.70539 \\
3 & -2734.37 & 101.926 & $5.82 \mathrm{E}+23$ & 77.22026 & 83.35377 \\
4 & -2655.39 & 89.36916 & $5.25 \mathrm{E}+23$ & 76.82612 & 84.92235 \\
5 & -2549.21 & 97.8 & $2.93 \mathrm{E}+23$ & 75.71605 & 85.775 \\
6 & -2456.84 & 65.63496 & $3.49 \mathrm{E}+23$ & 74.96933 & 86.99101 \\
7 & -2276.66 & $90.08768^{*}$ & $8.33 \mathrm{e}+22^{*}$ & $71.91209^{*}$ & 85.89649 \\
\hline
\end{tabular}

Notes: Robust standard errors in brackets, ${ }^{*},{ }^{* *},{ }^{* *}$ significance: $\mathrm{p}<0.1, \mathrm{p}<0.05, \mathrm{p}<0.01$.

Table 3. Variables cointegration test.

\begin{tabular}{ccccc}
\hline \multicolumn{2}{c}{ Hypothesized } & Trace & 0.05 & \\
\hline No. of CE $(\mathrm{s})$ & Eigen value & Statistic & Critical Value & Prob. \\
\hline None & 0.791408 & 324.9965 & 143.6691 & 0 \\
At most 1 & 0.676502 & 205.876 & 111.7805 & 0 \\
At most 2* & 0.479083 & 120.1054 & 83.93712 & 0 \\
At most 3* & 0.375204 & 70.54085 & 60.06141 & 0.0051 \\
At most 4 & 0.194215 & 34.79575 & 40.17493 & 0.1567 \\
At most 5 & 0.124996 & 18.38445 & 24.27596 & 0.2308 \\
At most 6 & 0.094019 & 8.236416 & 12.3209 & 0.2189 \\
At most 7 & 0.00959 & 0.732384 & 4.129906 & 0.4504 \\
\hline
\end{tabular}

Notes: Robust standard errors in brackets, ${ }^{*},{ }^{* *},{ }^{* *}$ significance: $\mathrm{p}<0.1, \mathrm{p}<0.05, \mathrm{p}<0.01$. 
The significance level of covariance test was $5 \%$. At the $5 \%$ significance level, rejecting there were 3 cointegration variables, that is, there were at least four covariate vectors in the cointegration equation. It can be shown that the model is set correctly and that there is a balanced relationship between the variables in the long run. The VAR model can be further estimated.

\subsection{VAR Test}

The VAR test results are listed in Figure 2.

4) Impulse response analysis

On the basis of establishing VAR model, the impulse response function is used to analyze the influence of monetary factors and external shock on China's inflation.

Response to Cholesky One S.D. Innovations ?2 S.E.
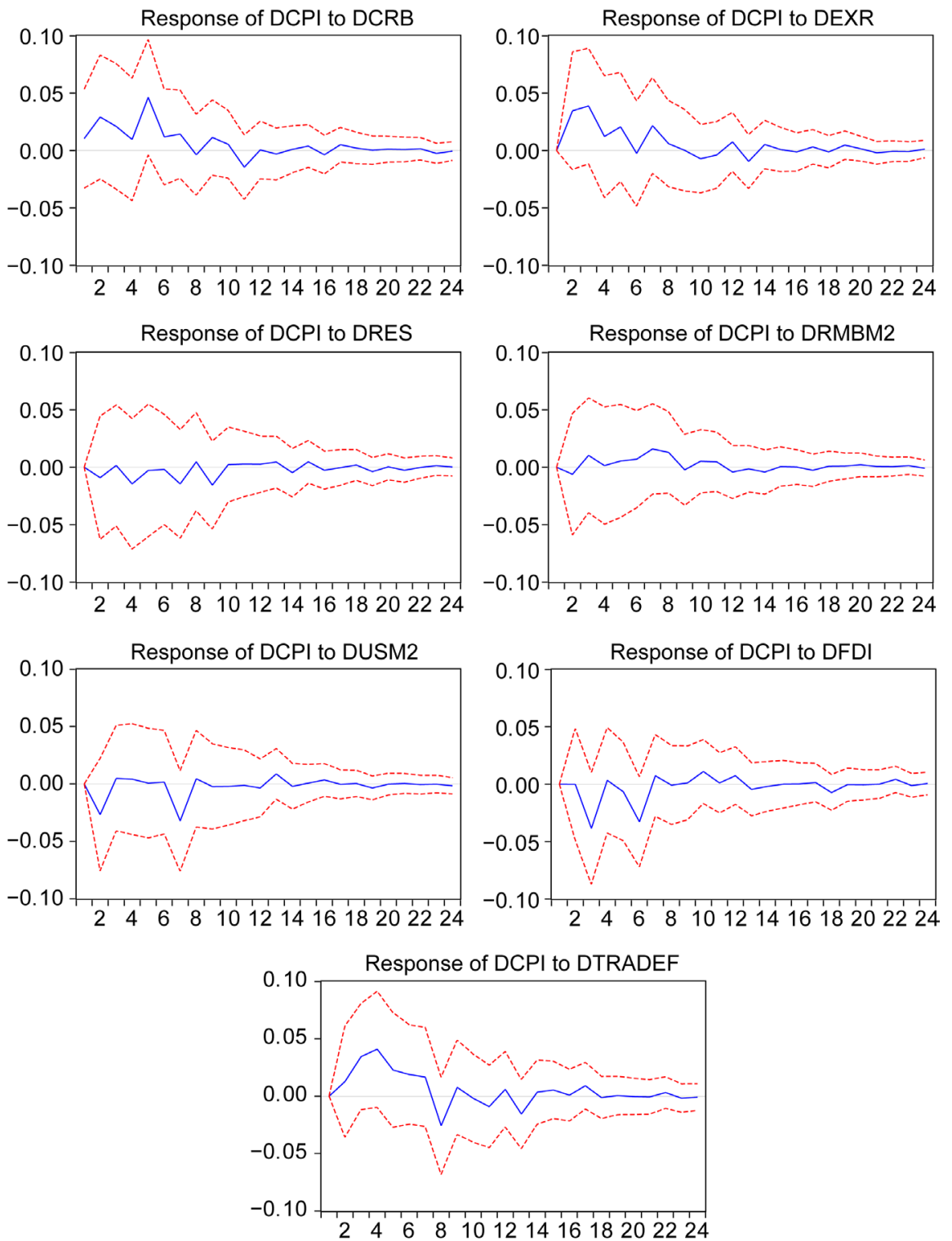

Figure 2. CPI impulse response function diagram. 
The impulse response function method mainly describes the dynamic effect of the model on the system when subjected to some kind of impact. The response variable of CPI is selected for each variable, and the dynamic change time interval is 24 , and the solid part is the impulse response function curve.

From the impulse response function chart, CPI response to the commodity price index, the dollar/RMB exchange rate, foreign direct investment and trade balance is more intense. The inflation index has a high sensitivity to the commodity price index, and the CRB has a positive impact on the CPI. It can be seen that the rise in the price level of the world's major commodities, including energy, grain and other raw materials, has pushed up the cost of production in the domestic manufacturing industry and thus reacted to the final commodity, forming an input-type inflation. The change in exchange rate also confirms this, China's long-standing trade surplus and the appreciation of the RMB is expected to accelerate the international capital, channeling investment or international hot money flow into China, which led to an inflation. CPI is also positive for the impulse response of the trade deficit, while reflecting a longer time lag. Note that the CPI response to China's money supply is small, indicating that the increase in money supply has a significant impact on the CPI is insignificant.

\subsection{Variance Decomposion}

To see variance decomposition based on VAR. From the impulse response diagram, we can intuitively see the impact of various factors on inflation, including the domestic money supply factors as well as external impact effect. The data reflects that China's inflation is greater influenced by external factors. Further variance decomposition of CPI, the results shown in Table 4.

From the variance of the Table 4, the consumer price index of its own interpretation is the largest, the value ranges between $67 \%$ and $99 \%$. The postponement of the commodity price index gradually increased to $7 \%$, the trade balance increased to $8 \%$, and the variance contribution of the US dollar/RMB exchange rate was $6 \%$. In view of this, the external factors accounted for a large proportion of the causes of inflation, and these factors in the latter part of the variance has the larger contribution, indicating that inflation in the international transmission to the country have a certain time lag.

\section{Conclusions and Inflation Response Policy Recommendations}

(A) Improve the efficiency of resource use, to resist the impact of rising external costs

From the empirical analysis, the US dollar QE brought that caused the rise in international commodity prices has an impact to China's inflation. In the future, China's economic development will continue to increase the demand for resource products, and China still relies on resource import in many fields [5]. Therefore, the long-term strategy is to improve the efficiency of resource utilization and actively develop alternatives energy to resist external costs. At the same 
Table 4. CPI variance table.

\begin{tabular}{|c|c|c|c|c|c|c|c|c|c|}
\hline Period & S.E. & DCRB & DCPI & DEXR & DFDI & DRES & DRMBM2 & DTRADEF & DUSM2 \\
\hline 1 & 35.154 & 0.295 & 99.704 & 0 & 0 & 0 & 0 & 0 & 0 \\
\hline 2 & 44.923 & 2.389 & 92.138 & 2.979 & $6.11 \mathrm{E}$ & 0.205 & 0.091 & 0.409 & 1.784 \\
\hline 3 & 48.694 & 2.896 & 83.630 & 5.592 & 3.067 & 0.176 & 0.297 & 2.805 & 1.534 \\
\hline 4 & 52.857 & 2.927 & 80.251 & 5.593 & 2.929 & 0.57 & 0.286 & 5.945 & 1.489 \\
\hline 5 & 54.137 & 6.734 & 75.555 & 6.041 & 2.834 & 0.556 & 0.323 & 6.552 & 1.401 \\
\hline 6 & 55.515 & 6.732 & 73.562 & 5.825 & 4.644 & 0.543 & 0.398 & 6.932 & 1.353 \\
\hline 7 & 55.902 & 6.775 & 70.506 & 6.363 & 4.527 & 0.878 & 0.806 & 7.090 & 3.042 \\
\hline 8 & 56.88 & 6.686 & 69.456 & 6.317 & 4.454 & 0.902 & 1.069 & 8.086 & 3.027 \\
\hline 9 & 57.555 & 6.848 & 68.950 & 6.271 & 4.423 & 1.295 & 1.070 & 8.126 & 3.013 \\
\hline 10 & 58.179 & 6.852 & 68.751 & 6.315 & 4.593 & 1.296 & 1.107 & 8.080 & 3.001 \\
\hline 11 & 58.801 & 7.156 & 68.374 & 6.304 & 4.570 & 1.302 & 1.137 & 8.169 & 2.987 \\
\hline 12 & 58.883 & 7.125 & 68.206 & 6.371 & 4.640 & 1.307 & 1.161 & 8.192 & 2.997 \\
\hline 13 & 59.221 & 7.083 & 67.718 & 6.466 & 4.635 & 1.330 & 1.155 & 8.515 & 3.094 \\
\hline 14 & 59.503 & 7.070 & 67.644 & 6.496 & 4.632 & 1.364 & 1.181 & 8.516 & 3.095 \\
\hline 15 & 59.631 & 7.086 & 67.571 & 6.489 & 4.626 & 1.397 & 1.180 & 8.554 & 3.092 \\
\hline 16 & 59.806 & 7.104 & 67.534 & 6.489 & 4.624 & 1.407 & 1.180 & 8.550 & 3.109 \\
\hline 17 & 60.007 & 7.128 & 67.403 & 6.489 & 4.616 & 1.403 & 1.189 & 8.664 & 3.103 \\
\hline 18 & 60.099 & 7.128 & 67.333 & 6.485 & 4.697 & 1.408 & 1.188 & 8.657 & 3.099 \\
\hline 19 & 60.197 & 7.122 & 67.278 & 6.517 & 4.694 & 1.431 & 1.189 & 8.650 & 3.117 \\
\hline 20 & 60.32 & 7.123 & 67.263 & 6.517 & 4.693 & 1.431 & 1.196 & 8.649 & 3.117 \\
\hline 21 & 60.386 & 7.123 & 67.259 & 6.522 & 4.692 & 1.441 & 1.196 & 8.648 & 3.116 \\
\hline 22 & 60.460 & 7.122 & 67.228 & 6.519 & 4.7174 & 1.440 & 1.196 & 8.658 & 3.115 \\
\hline 23 & 60.567 & 7.131 & 67.213 & 6.519 & 4.718 & 1.443 & 1.198 & 8.660 & 3.114 \\
\hline 24 & 60.579 & 7.130 & 67.207 & 6.521 & 4.718 & 1.443 & 1.200 & 8.660 & 3.118 \\
\hline
\end{tabular}

time, enhancing the pricing power in the international commodity market is also an effective way to cope with rising commodity prices. For important energy, it is vital to strengthen international cooperation and investment, which is a reasonable use of large foreign exchange reserves.

(B) Accelerate the transformation and upgrading of the economy, optimize the export structure

The low value-added value of primary products in China has been a major obstacle to the economic development. There are still serious problems such as overcapacity. These industries are urgently required to upgrade and upgrade our economy, increasing the proportion of service industry and gradually improve through independent innovation, product pricing capacity and reform of China's industrial structure. Additionally, China should take the initiative to control 
the long-term trade surplus by implementation of active and effective fiscal policy. It can manipulate macro-control measures gradually to decline the reliance on the export trade, and carry out stimulation of domestic demand to control unnecessary export trade surplus.

(C) To accelerate the process of internationalization of RMB, improve the exchange rate formation mechanism

Currently, dollar is still the world's main settlement currency. The dollar's 4 rounds of QE have significantly pushed up the international commodity prices, and had a negative impact on China's imports. At present, the voice of internationalization of RMB is becoming more and more intense, and the internationalization of RMB has been continuously improved. This is an important moment when we seize the opportunity to speed up the process. By speeding up the opening degree of the financial industry, signing the RMB settlement contract and actively participating in the multilateral cooperation between the regions has made the international status of the RMB higher [6]. At the same time, China should adhere to the principle of the initiative to enhance the flexibility of exchange rate formation, implementing a more transparent and more marketoriented exchange rate system.

(D) Improve the ability of conducting monetary policy

Since the financial crisis, in order to cope with the downward pressure on the economy, China adopted a more lenient monetary policy, which included a large amount of capital injection to stimulate industrial development. Although in the short-term it has achieved the desired effect, preventing the economic contraction, but under the spread of the international currency shock, China's inflation is more and more obvious, and ultimately restricts economic development. These problems put forward higher demands on the central bank's monetary policy operation. The central bank should strengthen the monitoring of the quantity and price index and develop the multi-channel means to deal with the threat of inflation so as to adapt the money supply to the actual demand of economic development.

\section{References}

[1] Benati, L. (2009) Long-Run Evidence on Money Growth and Inflation. Social Science Electronic Publishing, 179, 22-25.

[2] Rapch, D.E. (2003) International Evidence on the Long-Run Impact of Inflation. Journal of Money Credit \& Banking, 35, 23-48. https://doi.org/10.1353/mcb.2003.0005

[3] He, Z.Q. (2012) Study of the Influence of the American QE Effects on China's Monetary Inflation. Science of Finance \& Economics, 10-11.

[4] Zhang, L.Q. (2011) The Shock of QE II and the Policy Selection of Chinese Monetary Policy. International Economic Review, 1, 50-56.

[5] (2014) Research on the Effect of External Shock on Inflation in China. Financial Development Review, 3.

[6] Peng, H.X. (2014) China's Current Causes of Inflation and Governance Research. Central South University Master's Degree Thesis. 
Submit or recommend next manuscript to SCIRP and we will provide best service for you:

Accepting pre-submission inquiries through Email, Facebook, LinkedIn, Twitter, etc. A wide selection of journals (inclusive of 9 subjects, more than 200 journals)

Providing 24-hour high-quality service

User-friendly online submission system

Fair and swift peer-review system

Efficient typesetting and proofreading procedure

Display of the result of downloads and visits, as well as the number of cited articles Maximum dissemination of your research work

Submit your manuscript at: http://papersubmission.scirp.org/

Or contact ajibm@scirp.org 